University of Wollongong

Research Online

Faculty of Engineering and Information

Faculty of Engineering and Information

Sciences - Papers: Part B

Sciences

2017

Behaviour of subballast reinforced with used tyre and potential application in rail tracks

Buddhima Indraratna

University of Wollongong, indra@uow.edu.au

Qideng Sun

University of Wollongong, qideng@uow.edu.au

Jim Grant

Ecoflex International, Jim@ecoflex.com.au

Follow this and additional works at: https://ro.uow.edu.au/eispapers1

Part of the Engineering Commons, and the Science and Technology Studies Commons

Research Online is the open access institutional repository for the University of Wollongong. For further information contact the UOW Library: research-pubs@uow.edu.au 


\title{
Behaviour of subballast reinforced with used tyre and potential application in rail tracks
}

\begin{abstract}
Rubber tyres have a three dimensional cylindrical structure, and as such could be used to stabilise foundations by increasing the bearing capacity and reducing settlement for transport infrastructure. It is therefore expected that in railroad engineering, a capping layer reinforced with rubber tyres could help to reduce the thickness of the granular layer (i.e. ballast), improve the track bearing capacity, and reduce the frequency of maintenance. However, there is a notable gap between the conceptual theories and real-life applications pertaining to the mechanisms of rubber tyre-reinforced foundations. In pavement engineering, the bearing capacity is closely linked to plate load tests. In this study, plate load tests were carried out on a single tyre filled with subballast material and subjected to a vertical load. This testing process was then modelled using the Finite Element software ABAQUS to study and quantify the interaction between the tyre and the granular medium. The experimental and numerical results reveal that the rubber tyre can significantly increase the modulus and ultimate bearing capacity of the granular layer. The numerical process was further extended to a finite element track model to demonstrate the expected response of a ballasted railway track with and without tyre reinforcement.

\section{Disciplines}

Engineering | Science and Technology Studies

\section{Publication Details}

Indraratna, B., Sun, Q. \& Grant, J. (2017). Behaviour of subballast reinforced with used tyre and potential application in rail tracks. Transportation Geotechnics, 12 26-36.
\end{abstract}




\section{Behaviour of Subballast Reinforced with Used Tyre and Potential Application}

\section{in Rail Tracks}

4

5

6

7

Buddhima Indraratna, PhD (Alberta), FTSE, FIEAust., FASCE, FGS

Professor of Civil Engineering and Research Director,

Centre for Geomechanics and Railway Engineering;

Program Leader, ARC Centre of Excellence for Geotechnical Science and Engineering;

University of Wollongong, Wollongong, NSW 2522, Australia.

E-mail: indra@uow.edu.au

Qideng Sun, PhD (University of Wollongong)

Research Associate, Centre for Geomechanics and Railway Engineering,

University of Wollongong, Wollongong NSW 2522, Australia.

E-mail: qs349@uowmail.edu.au

\section{Jim Grant}

Manager, Ecoflex International Pty Ltd, Avoca Beach NSW 2251, Australia.

Eamil: Jim@ecoflex.com.au

Words: 4729; Figures: 15; Tables: 2; Date of Submission: 13/01/2017

Submitted to: Transportation Geotechnics

Author for correspondence:

Prof. Buddhima Indraratna,

University of Wollongong,

Wollongong, NSW 2522, Australia.

Ph: +61 242213046

Fax: +61242213238

Email: indra@uow.edu.au 


\section{ABSTRACT}

Rubber tyres have a three dimensional cylindrical structure, and as such could be used to stabilise foundations by increasing the bearing capacity and reducing settlement for transport infrastructure. It is therefore expected that in railroad engineering, a capping layer reinforced with rubber tyres could help to reduce the thickness of the granular layer (i.e. ballast), improve the track bearing capacity, and reduce the frequency of maintenance. However, there is a notable gap between the conceptual theories and real-life applications pertaining to the mechanisms of rubber tyre-reinforced foundations. In pavement engineering, the bearing capacity is closely linked to plate load tests. In this study, plate load tests were carried out on a single tyre filled with subballast material and subjected to a vertical load. This testing process was then modelled using the Finite Element software ABAQUS to study and quantify the interaction between the tyre and the granular medium. The experimental and numerical results reveal that the rubber tyre can significantly increase the modulus and ultimate bearing capacity of the granular layer. The numerical process was further extended to a finite element track model to demonstrate the expected response of a ballasted railway track with and without tyre reinforcement.

Key words: used tyre, reinforcement, gravel, rail track, Finite Element Modelling

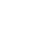




\section{INTRODUCTION}

There is an ongoing demand in Australia and around the world to increase the speed and freight capacity of railroad transportation, but heavier axle loads and higher speeds could exert higher dynamic wheel loads on track structure with more repetitions; as a consequence, a soft subgrade may experience higher repeated stresses which may lead to progressive shear failure and excessive deformation ( $\mathrm{Li}$ and Selig, 1998a). Moreover, under heavier dynamic loads the existing railway track may degrade further and faster due to unacceptable track deformation and the lateral spread of ballast, all of which leads to more frequent maintenance (Sun et al., 2016).

Over the past decades, geosynthetics such as geogrid and geocell have been used to improve the performance of embankments (Bathurst and Raymond, 1987; Göbel et al., 1994; Raymond, 2002; Shin et al., 2002; Raymond and Ismail, 2003; Brown et al., 2007; Fernandes et al., 2008; Indraratna et al., 2006; Webster and Alford, 1978). Several studies have already demonstrated that geogrid reinforcement reduces the settlement and degradation of ballast (Bathurst and Raymond, 1987; Brown et al., 2007; Indraratna and Salim, 2003; Indraratna et al., 2007; Qian et al., 2015). The main principle of geogrid reinforcement is to provide better grain interlocking that restricts the lateral movement of ballast. A layer of geogrid and geotextiles placed at the interface between ballast and subballast often gives encouraging results (Giroud and Han, 2004; Shin et al., 2002). Geocell arrangements could provide additional internal confining pressure and reinforcement to the gravel, which would then reduce the maintenance costs and enhance track serviceability. When a geogrid is installed between the layers of ballast and subballast, it interacts with the surrounding grains to carry the tensile loads imposed by repeated train loadings. However, this interaction depends primarily on the geometry, stiffness and cross-sectional shape of the rib, and its strength at the junctions (Shukla and Yin, 2006; Brown et al., 2007; Palmeria, 
2009). Railway organizations do not usually use geocells to confine the upper ballast because it may lead to problems with track maintenance when machinery is used to replace the ballast; but despite this problem, reinforcing the underlying subballast with geocells is an economic and feasible alternative (Indraratna et al, 2015). During loading, additional confinement is mobilised in the geocell which helps to stop the granular mass of subballast from spreading laterally, and by increasing the rigidity of the infill, geocells also improve the load-carrying capacity (Zhang et al., 2010; Leshchinsky and Ling, 2012; Sitharam and Hegde, 2013), which in turn improves track performance. Past studies have shown that cellular confinement significantly improves the strength and stiffness of a granular material, even though a lack of generic design methodology has inhibited its implementation (Han et al., 2008).

Scrap tyres are a major source of pollution and pose a serious threat to public health through releasing chemicals and pollutants into the environment. It is estimated that in Australia there are approximately 50 million tyre equivalent passenger units entering the waste stream annually, and this is a major issue for the use of landfill, stockpiles, and illegal dumping. The current reuse of waste tyres for infrastructure is limited because there is no rigorous scientific approach to innovative design and/or to quantify performance through comprehensive field studies, and furthermore, the need to design rail tracks upon which trains could travel at higher speeds is an enormous challenge to the stability and load bearing capacity of present track substructure.

This study will examine the performance of a subballast capping layer reinforced with rubber tyres used to minimise track deformation and improve its bearing capacity. The test system involves a tyre where one sidewall is removed and the tyre is then filled with gravel; a geotextile might then be placed between the rubber tyre and the ground. This concept and application of a tyre-reinforced granular system has three primary engineering benefits: (i) the confinement 
provided by the tyre cell would help to increase the stiffness of the contained aggregate, which then reduces vertical strains within the capping and ballast layers; (ii) prevents any lateral movement of the capping material, which would then reduce the deformation of the overlying ballast; and (iii) improves the flexural stiffness of the capping layer which distributes the traffic loads and reduces the maximum vertical stress on the subgrade. The technology proposed in this research is for subballast application, which is a continuous geo-mattress that supports the ballast layer rather than simply placing whole tyres in individual locations within the top ballast layer as possibly trialled elsewhere (but no published scholarly papers found by the authors). Placing tyres in the ballast layer will create practical problems in view of maintenance requirements plus the need to adhere to stringent constitutionalised standards of ballast placement and compaction in some countries such as Australia. The proposed applications in this study are designed to ensure that track construction and subsequent maintenance efforts are not hampered by interference with the tyre cells.

In this study, plate load tests were carried out to investigate the load transfer mechanisms between infill and tyre, and then a finite element model was established to simulate this plate loading procedure. Subsequently, the numerical predictions were compared with experimental results to validate the numerical procedure. Having calibrated the FEM model with a single tyre unit, a plane strain section of half a ballasted substructure was simulated to examine how the foundation would react under load, with or without being reinforced by tyres. The behaviour observed during the numerical simulation included vertical track settlement, the lateral displacement and the deviator stress of the subgrade which represents the combined influence of both vertical and confining stresses. 


\subsection{Material Properties}

124

125

126

The subballast (crushed basalt) used in this study came from a local quarry near Wollongong, NSW Australia. The particle size distribution (PSD) for the subballast was within the range specified by the rail industry, as shown in Fig. 1. Direct shear tests were carried out at lower normal stresses to represent the test conditions. The direct shear tests produced a peak friction angle of $39^{\circ}$ for this material at $70 \%$ relative density (Biabani and Indraratna, 2015).

A rubber tyre (one side wall removed) with an outside diameter of $560 \mathrm{~mm}$, a rim diameter of $330 \mathrm{~mm}$, a width of $150 \mathrm{~mm}$ was used to reinforce the subballast. The tensile stress and strain relationships of the rubber were determined by tensile tests conducted in accordance with ASTM D4885-01(2011) at a strain rate of 10\%/min, and are shown in Fig. 2. The mean tensile stresses at strains of $2 \%$ and $5 \%$ were 6.1 and $15.2 \mathrm{MPa}$ respectively, and the mean ultimate tensile strength was around $19.45 \mathrm{MPa}$. The average thickness of the rubber tyre was around $10 \mathrm{~mm}$, and its tensile stiffness was based on the tensile stress and strain relationship.

In this study, a $80 \mathrm{kN}$ woven geotextile of $2 \mathrm{~mm}$ thickness was placed under the rubber tyre for testing purposes; it was manufactured from durable, high-modulus polypropylene yarns woven into a robust, dimensionally stable geotextile. Physical characteristics and technical specification of subballast, subgrade, tyre and geocell used for the study are shown in Table 1.

\subsection{Test Setup and Procedures}

Six plate load tests were carried out in a test box (i.e. $800 \mathrm{~mm}$ long, $600 \mathrm{~mm}$ wide and $400 \mathrm{~mm}$ high) to investigate the load transfer mechanisms between the infill and rubber tyre, and the 200 
mm diameter loading plate set up is shown in Fig. 3. The sample was prepared (in a dry condition) by placing a $50 \mathrm{~mm}$ thick layer of compacted clayey sand into the test box to simulate the subgrade soil under the track. The subballast layers were $150 \mathrm{~mm}$ and $350 \mathrm{~mm}$ thick, and they were compacted to a density of $2100 \mathrm{kN} / \mathrm{m}^{3}$ in two and four layers, respectively. Compaction was carried out using a vibratory hammer. In the cases where the subballast was reinforced with a rubber tyre, the tyre unit was placed within the test box and then backfilled with gravel. The subballast was both inside and outside the tyre, but a woven geotextile was also placed beneath the tyre to prevent the dissimilar soils from mixing and to allow each soil layer in the test to function as intended. The high tensile strength and low elongation properties of woven geotextiles added further reinforcement to the test sample. With the $350 \mathrm{~mm}$ thick subballast, the samples with and without geotextiles were tested and compared. Two 30mm long strain gauges were attached to the interior wall of the tyre to measure the axial and circumferential strains. The surface of the tyre was brushed lightly with a cleaner and degreaser, and an industrial adhesive was applied before mounting the strain gauge. A stainless steel pressure cell (thickness $=10 \mathrm{~mm}$, diameter $=50 \mathrm{~mm}$, range $=500 \mathrm{kPa}$, accuracy $=99.7 \%$ ) was installed at the interface between the subballast and subgrade to measure the vertical pressure transmitted to the subgrade, as shown in Fig. 3. Another test was designed to evaluate the bearing capacity of a unit cell of rubber tyre and gravel composite; in this test the loading plate was $560 \mathrm{~mm}$ and the subballast was placed inside the tyre. Lateral spreading of the tyre was recorded by a linear voltage differential transformer (LVDT).

After the subballast was in place, the loading plate was placed on top of the test sample subjected to a vertical load. The centre of the plate coincided with the centre of the rubber tyre. Controlled displacement tests were carried out at a rate of $0.2 \mathrm{~mm} / \mathrm{min}$. The vertical load, axial and lateral 
displacement, and the strain that developed inside the tyre were recorded every second during the test.

\subsection{Test Results}

The results of six plate load tests on unreinforced and reinforced subballast are shown in Fig. 4. In Fig. 4(a \& b) for a load of $600 \mathrm{kPa}$, the vertical stress at the centre of the tyre, and at the interface between the subballast and subgrade was $470 \mathrm{kPa}$ and $264 \mathrm{kPa}$ for Test 1 without reinforcement and Test 2 with reinforcement, respectively. The inclusion of a rubber tyre and geotextile reinforcement reduced the stress transmitted to the subgrade, unlike the subgrade without reinforcement. Similarly, for a $600 \mathrm{kPa}$ load, the stress decreased from $470 \mathrm{kPa}$ to 82 $\mathrm{kPa}$ as the subballast increased in thickness from $150 \mathrm{~mm}$ to $350 \mathrm{~mm}$ in Test 1 and Test 3, respectively (Fig. 4a \& c). As expected, the increment of subballast thickness reduced the stress at the interface between the subballast and subgrade. This implies that the rubber tyre and geotextile reinforcement can effectively reduce the thickness of gravel required for real-life track design. The apparent vertical stiffness of the sample, as represented by the initial and linear portion of the load-displacement curve (at $2 \%$ strain), could be calculated from the test data in Fig. 4(c\&d). In Test 3, without reinforcement, the apparent stiffness was approximately 51.9 $\mathrm{kPa} / \mathrm{mm}$, but in Test 4 with tyre and geotextile reinforcement, the approximate stiffness was 78.4 $\mathrm{kPa} / \mathrm{mm}$. This result indicated that with reinforcement, Test 4 showed a $51 \%$ gain in stiffness compared to Test 3 without reinforcement. When Test 4 (Fig. 4d) in which geotextile was used, is compared to Test 5 (Fig. 4e), the results indicate that the geotextile provides further reinforcement effect. This is more beneficial in the case of thicker layer of subballast. 
The strain gauges attached to the inner surface of the tyre confirmed that the strain in the tyre was very small; with circumferential tensile strains of $0.015 \%, 0.061 \%$ and $0.060 \%$ under vertical loads of 940, 1610 and $1600 \mathrm{kPa}$ for Tests 2, 4, and 5 respectively, as shown in Fig. 5 (a, b \& c). The axial compressive strains for the tyre were $0.0051 \%, 0.0085 \%$ and $0.0027 \%$, respectively. It is very convincing that the tyre could confine the infill materials and maintain its original shape, unlike geocell reinforcement which deforms substantially under testing.

Without doubt the main parameter impacted by utilizing a tyre reinforcement unit is the bearing capacity of the soil, because, the cylindrical structure of the tyre confines the infill material, minimises lateral displacement, and increases its rigidity. Test 6 was carried out on a sample of subballast reinforced with a single tyre, as shown in Fig. 4(f). Here the vertical load reached $6500 \mathrm{kPa}$ with $19.2 \%$ axial and $3.3 \%$ lateral strains. The strains measured from the inner surface of the tyre are shown in Fig. 5(d), and although the circumferential tensile strain is small $(=1.2 \%$ in the end of the test), it will induce an additional confining stress $\Delta \sigma_{3}$ from the rubber tyre to the subballast. In the sample reinforced with a rubber tyre, any further confining stress can be generated through the hoop stress. By assuming that the internal friction angle of gravel for the reinforced sample remained constant, Bathurst and Karpurapu (1993) proposed using the apparent cohesion $c_{r}$ to account for the increasing strength of the geocell. The apparent cohesion $c_{r}$ was a result of the increased confining stress $\Delta \sigma_{3}$ provided by the geocell onto the infill soil where $c_{r}=\Delta \sigma_{3} / 2 \cdot \tan (\pi / 4+\emptyset / 2)$, and $\emptyset\left(=39^{\circ}\right)$ is the friction angle of the subballast. The increased stress $\Delta \sigma_{3}$, as suggested by Bathurst and Karpurapu (1993), can be estimated by the following equation: $\Delta \sigma_{3}=2 M / d \cdot\left[1-\left(1-\varepsilon_{a}\right)^{0.5}\right] /\left(1-\varepsilon_{a}\right)$, where $M(=1325000 \mathrm{~N} / \mathrm{m})$ is the tensile stiffness of the rubber tyre, $d(=0.56 \mathrm{~m})$ is the initial diameter of the rubber tyre pocket, and $\varepsilon_{a}$ is the axial strain of the sample. 
Fig. 4(f) shows that as the load increased, displacement increased in the axial and lateral directions, and as a consequence, further confining stress was induced from the tyre to the subballast by the lateral expansion. The variation of additional confinement $\Delta \sigma_{3}$ and apparent cohesion $c_{r}$ of the sample is shown in Fig. 6. Here, an increase in the applied stress generally increased $\Delta \sigma_{3}$ and $c_{r}$. There was a sharp increase of $\Delta \sigma_{3}$ when the load was relatively small (i.e. less than $500 \mathrm{kPa})$. As the applied load continued, the additional confining stress $\left(\Delta \sigma_{3}\right)$ increased at a decreasing rate, but for applied stress greater than $4000 \mathrm{kPa}, \Delta \sigma_{3}$ increased at a higher rate.

\section{NUMERICAL MODELLING OF THE TYRE-SUBBALLAST UNIT}

\subsection{Models and Material Properties}

The commercially available FE software ABAQUS (Hibbitt, Karlsson and Sorensen Inc. 2014), was used in this analysis. To investigate the interaction between the rubber tyre and the subballast, Tests $(3 \& 5)$ with and without tyre reinforcement respectively, were modelled and analysed. The mesh for the reinforced case is shown in Fig. 7(a) as an example, and there was no tyre in the model used for the unreinforced test.

To correctly characterize the tested materials and to attain acceptable results in the Finite Element analysis, reliable testing procedures and correct material data must be adopted. Both subballast and subgrade, in this paper, are represented with a standard Mohr-Coulomb model (linear elastic-perfectly plastic), which has been commonly used to simulate granular materials in transport infrastructure in past well-known studies too (Indraratna and Nimbalkar, 2013; Sayeed and Shahin, 2016). The material parameters for the MC model can be determined using wellestablished laboratory methods (consolidation and shear). 
The relevant deformation and strength properties were obtained from direct shear tests (Biabani and Indraratna, 2015) and large scale cubical triaxial tests (Indraratna et al., 2015). The MC model involves five basic parameters (i.e., Young's modulus $E$, Poisson's ratio $v$, effective cohesion $c^{\prime}$, effective friction angle $\phi$, and dilation angle $\psi$ ). In this study, a subballast with the following properties: $E=2 \mathrm{MPa}, v=0.3, \phi=39^{\circ}$ and $\psi=15^{\circ}$ has been considered. A small cohesion value of $1 \mathrm{kPa}$ was assigned to the subballast to improve numerical stability and to avoid modelling difficulties such as strain localisation issues at or near sharp singularities (rate of convergence). The rubber tyre was modelled discretely as an elastic material because there was no evidence of plastic damage encountered during the tests. Contact between the rubber tyre and the gravel was modelled as a 'hard normal contact' (i.e. cannot penetrate rubber), and the tangential coefficient of friction was specified by the tangent of two thirds of the internal angle of friction (i.e. 0.45), as is commonly used for soil-reinforcement interaction (Leshchinsky and Ling, 2012). Table 2 summarises the material properties used in this analysis.

The test box was modelled in such a way where the vertical movement was fixed at the bottom boundary and the horizontal movement was fixed along the four side boundaries. Vertical movement was allowed on the top $200 \mathrm{~mm}$ diameter surface to simulate the vertical load applied by a rigid plate. The actual experimental and Finite Element simulation were run under displacement-control conditions. Throughout these simulations the vertical displacement and stress under the loading plate, as well as the pressure transmitted to the surface between subballast and subgrade, were compared with the actual test results.

The tyre cell used in this study has an aspect ratio (height/diameter) of 0.27 . Thus the conventional aspect ratio of 2 used in testing of earthen materials cannot be used when testing soil confined in a single tyre cell. It is known that aspect ratio influences the shear strength of 
soil measured in triaxial compression (Bishop and Green, 1965). The authors agree that the test results in this study may not replicate the exact field data because of the inevitable boundary conditions of the test setup. While recognizing this as a limitation, the observed results still indicate the benefits of the rubber tyre reinforcement albeit not being able to directly translate the magnitudes of experimental measurements to the field.

However, in order to study the implications of boundary and dimensional effects, a sensitivity analysis was carried out for a reinforced model with varying dimensions. Maximum lateral displacements of the tyre reinforced subballast obtained from the models were compared at a load displacement of $40 \mathrm{~mm}$ (Figure $7 \mathrm{~b}$ ). The results show that when the model (mesh) dimension is increased, the maximum lateral displacement decreases, and when the maximum dimension is greater than $3 \mathrm{~m}$, the corresponding decrease in lateral displacement becomes insignificant. Based on these preliminary observations, it can be concluded that the effect of boundary conditions may only be marginal when the mesh dimension is at least 5 times that of the tyre diameter.

\subsection{Numerical Results and Analyses for Laboratory Testing}

As Fig. 4(c \& e) shows, the load-deformation relationships for reinforced and unreinforced tests agreed reasonably well with the experimental and FEM analysis results, and moreover, the vertical displacements decreased by the inclusion of a rubber tyre for the same load magnitude, which agrees with the experimental results. The main benefit of a rubber tyre is to confine the subballast, as shown by the tests results in Fig. 6, while Fig. 8 shows the patterns of vertical and lateral displacement for the unreinforced and reinforced test simulations. Fig. 8 (a \& b) also shows that the patterns for the two cases were similar, i.e. compression under the load plate, but 
vertical displacement for the unreinforced subballast was greater than the reinforced subballast, albeit under the same vertical load.

Fig. 8(c \& d) show the contours of lateral displacement for the unreinforced and reinforced cases, and they show that the largest lateral displacement developed under the edge of the load plate. The comparisons in Fig. 8(c \& d) show that the maximum lateral displacement for unreinforced subballast was approximately 1.8 times more than the reinforced subballast under the same load. Clearly, this reduction in horizontal displacement of the reinforced set up has resulted due to the confinement provided by the rubber tyre.

Lateral deformation along the $\mathrm{x}$-direction of the tyre is shown in Fig. 9. Here the numerical simulation indicates that the rubber tyre expanded outwards as shown in Fig. 4(f). As the applied pressure increased from $50 \mathrm{kPa}$ to $1500 \mathrm{kPa}$ the maximum displacement of the rubber tyre increased from $0.077 \mathrm{~mm}$ to $2.44 \mathrm{~mm}$, but when the load is relatively small (i.e. $50 \mathrm{kPa}$ ), maximum displacement occurred around the mid-height of the tyre. When the load increased to $1500 \mathrm{kPa}$, the maximum displacement moved towards the bottom of the tyre while the top edge moved inwards, as shown in Fig. 9.

Fig. 10 shows the forces in the tyre at $1500 \mathrm{kPa}$; there is compression near the top edge of the tyre which corresponds to an inward movement of the top edge as shown in Fig. 9. Moreover, tension developed in the tyre in the lateral direction (Fig. 10) where it was highest approaching the bottom edge of the tyre. This result is consistent with the distribution of displacement shown in Fig. 9. The shear stresses at the interface between the tyre and subballast are presented in Fig. 11 ( $\&$ b), where the highest interface shear stresses developed near the bottom and close to the edge of the tyre. 
Validation through numerical modelling adds credibility when simulating a practical application of a tyre-reinforced railway track. Hence, a finite element 3D analysis was conducted to model the behavior of the capping layer composed of infilled rubber tyres.

\subsection{Track System Geometry}

As with a traditional railway track system, the steel rails in this study are supported on reinforced concrete sleepers spaced at $0.60 \mathrm{~m}$ centres. The rail head is $0.075 \mathrm{~m}$ wide, the web is $0.018 \mathrm{~m}$ wide, and the base $0.15 \mathrm{~m}$ wide. The concrete sleepers were embedded into a layer of coarse granular aggregate (ballast). For a standard gauge track, a sleeper of $2.50 \mathrm{~m}$ in width was

307

308

309

310

\subsection{Loading}

The analysis was based on a typical modern freight car used by Australian railways to transport heavy bulk materials such as coal, construction materials, and aggregates. Traditionally, these have an axle load of 25 tonnes, which corresponds to a static wheel load of $122.5 \mathrm{kN}$. It is common practice to conduct a pseudo-static analysis in which the dynamic effects are considered by multiplying the static load by a dynamic amplification factor (DAF). In conventional practice, DAF is used as a function of static (wheel) load and train velocity to obtain the equivalent dynamic load (Li and Selig, 1998b). The American Railway Engineering Association (AREA) 
recommends the expression for $D A F=1+0.0052 V / D$, where $V$ is the train velocity in kilometres per hour and $D$ is wheel diameter in metres (AREA, 1996). A 25t axle load train moving at 100 $\mathrm{km} / \mathrm{h}$ speed was simulated in this study.

\subsection{Finite Element Model for Rail Track}

A plane strain slice of the cross section of half a ballasted railway substructure was modelled by a finite element mesh refined to observe the track settlement, lateral displacement of the ballast slope, and the subgrade stress of the foundation with or without rubber tyres reinforcing the subballast layer. The ballast was modelled as linearly elastic-perfectly plastic material with a Mohr-Coulomb failure criterion. The material parameters for the subballast, subgrade, and rubber tyre were the same as the plate load test simulation (Table 2). The tyres were modelled as perfect cylinders, and the contact between the tyres was considered smooth for simplicity. The sleepers and rails were modelled as non-yielding linear elastic material, whose significantly greater stiffness compared to the ballast, foundation and rubber tyres, replicated a composite structure (Table 2).

To properly configure a railway structure requires a true three-dimensional (3D) Finite Element analysis, but the track width along the assumed plane strain direction could be established by considering the loading characteristics and boundary conditions. Selig and Waters (1994) suggested that based on track deflections, a set of three sleepers would be sufficient to represent track response in the longitudinal direction. The transverse width of the plane strain model was assumed to be $1.9 \mathrm{~m}$, and by exploiting centreline symmetry, only half the track was modelled. The FEM mesh with the subballast reinforced with rubber tyres consisted of 22548 elements and 36761 nodes (Fig. 13), while the model with unreinforced (no tyres) subballast only consisted of 
15050 elements and 24608 nodes. The ballasted track and foundation were meshed with hexahedral 8-noded elements with reduced integration points (C3D8R). Interaction between different layers of gravel was modelled with the same strategy used to simulate the unit cell. In order to simulate railway field conditions, plane strain condition was applied to the model where the strain in the longitudinal direction was considered insignificant compared to lateral transverse strain. By taking advantage of symmetry, only half of the embankment and foundation was modelled. The vertical planes along the outer edge of the foundation were constrained from lateral displacement in the x-direction, and the same constraint was affixed to the $\mathrm{x}-\mathrm{y}$ planes to prevent lateral displacement in the $\mathrm{z}$-direction. The base of the model was restricted from any displacement as conventionally required for a FEM mesh, i.e. non-displacement bottom boundary.

\subsection{Numerical Predictions}

In Railway engineering, the design is mainly based on limiting the traffic and load-induced deviator stress in the subgrade to levels that will protect the subgrade from progressive shear failure and excessive plastic deformation ( $\mathrm{Li}$ and Selig, 1998a). In order to maintain the track profile, ballast displacement (vertical and lateral) should be controlled within certain limits. This section of the paper will demonstrate how the subgrade deviator stress and ballast displacement can be influenced by the use of rubber tyres as reinforcement, in contrast to the unreinforced case. The input parameters used for the Finite Element Method analysis are listed in Table 2; note that a set of three sleepers were considered sufficient for the analysis, and the deviator stress discussed was directly under the central sleeper. 
Fig. 14(a) shows the effect that reinforcement offered by rubber tyres has on the deviator stress at the surface of the subgrade. As expected, the highest deviator stress occurs near the sleeper end and it decreases towards the central sleeper. This is consistent with the field observations where the largest subgrade depressions usually occur near the edges of the sleepers (Li and Selig, 1998a). With tyre-reinforcement, a train running with the same axle load (i.e. 25 ton) and speed (i.e. $100 \mathrm{~km} / \mathrm{h}$ ), experiences a maximum deviator stress of $46.2 \mathrm{kPa}$, which is almost a $12 \%$ reduction compared to that of an unreinforced section. Intuitively, the confining effect causes the tyres and gravel infill composite to act as a stiffer, flexible "mattress" which allows a reduced and more uniform stress to be transmitted to the subgrade. As shown in Fig. 14(a), the area that the traffic and load-induced subgrade stress was distributed to was wider than the area without tyre reinforcement.

Fig. 14(b) shows the effect that tyre reinforcement has on the distribution of deviator stress with the depth of subgrade. The deviator stress in the subgrade decreases with depth. Lateral deformation along the slope of the embankment also decreases considerably due to tyre reinforcement (Fig. 15). The contours of lateral displacement for the unreinforced and reinforced layers of subballast are also shown in Fig. 15, where the largest lateral movement of subballast developed beneath the edge of the sleeper in the reinforced subballast. These comparisons show that the maximum lateral displacement for unreinforced subballast $(0.095 \mathrm{~m})$ was considerably more than that of reinforced subballast $(0.012 \mathrm{~m})$ under the same load.

\section{CONCLUSIONS}

In this study, plate loading tests were carried out to investigate the load transfer mechanism between rubber tyre and infill material. The inclusion of rubber tyre and geotextile reinforcement 
could help to reduce the stress transmitted to the subgrade, and increasing the thickness of the subballast could also reduce stress at the interface between the subballast and subgrade. In a practical sense, the inclusion of rubber tyres and geotextile reinforcement can effectively reduce the design thickness of ballast, while eliminating the need for having a capping layer composed of natural rock aggregates. The experimental results showed that the tyre reinforcement could provide more than $50 \%$ gain in stiffness of a subballast (capping) layer. Due to its cylindrical structure, rubber tyres can confine the infill material, minimise lateral displacement, and provide a rigid capping with a bearing capacity of up to $6500 \mathrm{kPa}$ with substantial reduction in lateral strains. The measurements confirmed that the strain experienced by the rubber tyre was relatively small. An additional confining stress is generated by the hoop stress of the tyre, which can be as much as $500 \mathrm{kPa}$, at the maximum applied load of $6500 \mathrm{kPa}$.

A FEM study of plate loading test verified that the use of tyres could increase the elastic modulus of reinforced gravel by confinement. The maximum displacement and maximum tension inside the tyre were close to its bottom, and the highest interface shear stresses also developed near the bottom and close to the edge of the tyre. The load-deformation relationships for the reinforced and unreinforced cases agreed reasonably well in view of the experimental and FEM results.

The 3D Finite Element track model indicated that the highest deviator stress occurred near the edge of the sleeper, while the confining effect causes the tyre and gravel infill composite to act as a stiff but flexible "mattress" that can reduce the stress transmitted to the subgrade. This has significant implications on the stability of a soft subgrade that can prematurely yield unless the transmitted stress is reduced by a reinforced capping layer. 
In this study, plate load tests were carried out on a single tyre filled with subballast to investigate the load-settlement behaviour of the gravels under static load. The data of these tests was also used to validate and calibrate the numerical model. Cyclic loads testing program is still in progress and is premature to discuss herein. The cyclic tests have been set up with all the rail track components (e.g. rail, sleeper, ballast, tyre confined capping layer \& subgrade). Lateral deformation and settlement, time-dependent resilient modulus, damping and energy-based characteristics, particle degradation effects, as well as the axial and circumferential strains of the tyre cell upon cyclic loading will be presented and discussed in a future research paper.

\section{ACKNOWLEDGEMENTS}

The authors acknowledge the financial assistance provided by the NSW Environmental Trust, TSA and Ecoflex International Pty Ltd. Assistance of A/Prof Cholachat Rujikiatkamjorn and Dr Ana Heitor at various times during this project is gratefully appreciated. Laboratory assistance from M. Mahdi Biabani, Lucas Lima, Alan Grant, and Ritchie McLean is gratefully acknowledged. We also thank Julian Gerbino from Polyfabrics Australia for providing the woven Geotextile used in the tests.

\section{REFERENCES}

American Railway Engineering Association (AREA). Manual for railway engineering. vol. 1, AREA, Washington, D.C, 1996.

AS 3706.2, Determination of Tensile Properties-Wide Strip Method, Standards Australia, 2012.

AS 3706.9-12, Geotextiles - Methods of test-Determination of permittivity, permeability and flow rate, Standards Australia, 2012.

ASTM D4885-01. Standard test method for determining performance strength of geomembranes by the wide strip tensile method, ASTM International, West Conshohocken, PA, 2011.

Austroads, Guide to Geotextiles, Technical Report, Australia, January, 1990. 
Bathurst RJ, Karpurapu R. Large-Scale triaxial compression testing of geocell-reinforced granular soils. Geotechnical Testing J 1993; 16(3): 296-303.

Bathurst RJ, Raymond GP. Geogrid reinforcement of ballasted rail track. Transportation Research Record 1153, Transportation Research Record, Washington, DC, 1987.

Biabani MM, Indraratna B. An evaluation of the interface behavior of rail subballast stabilized with geogrids and geomembranes. Geotext and Geomembr 2015; 43: 240-49.

Brown SF, Kwan J, Thom NH. Identifying the key parameters that influence geogrid reinforcement of railway ballast. Geotext and Geomembr 2007; 25(6): 326-35.

Fernandes G, Palmeira EM, Gomes RC. Performance of geosynthetic-reinforced alternative subballast material in a railway track. Geosynth Int 2008; 15(5): 311-21.

Giroud JP, Han J. Design method for geogrid-reinforced unpaved roads. I. Development of design method. Int J Geotech Eng 2004;130 (8):775-86.

Göbel CH, Weisemann UC, Kirschner RA. Effectiveness of a reinforcing geogrid in a railway subbase under dynamic loads. Geotext and Geomembr 1994; 13(2): 91-9.

Han J, Leshchinsky D, Parsons RL, Rosen A, Yuu J. Technical review of geocell-reinforced base courses over weak subgrade. In: The First Pan-American Conference and Exhibition, vol. 1.1. Cancun, 2008. p. 1022-30.

Hibbitt, Karlsson, Sorensen Inc. ABAQUS User’s Manual, Version 6.14, 2014.

Indraratna B, Biabani MM, Nimbalkar S. Behavior of geocell-reinforced subballast subjected to cyclic loading in plane-strain condition. J Geotech Geoenviron Eng ASCE 2015; 141(1): 04014081.

Indraratna B, Khabbaz H, Salim W, Christie D. Geotechnical properties of ballast and the role of geosynthetics in rail track stabilization. Proceedings of the ICE-Ground Improvement 2006; 10 (3): 91-102.

Indraratna B, Nimbalkar S. Stress-strain degradation response of railway ballast stabilized with geosynthetics. J Geotech Geoenviron Eng ASCE 2013; 139(5): 684-700.

Indraratna B, Salim W. Deformation and degradation mechanics of recycled ballast stabilised with geosynthetics. Soils Found 2003;43(4):35-46.

Indraratna B, Shahin MA, Salim W. Stabilisation of granular media and formation soil using geosynthetics with special reference to railway engineering. Ground Improv 2007;11(1):27-43.

Leshchinsky B, Ling H. Effects of geocell confinement on strength and deformation behavior of gravel. J Geotech Geoenviron Eng ASCE 2012; 139(2): 340-52.

Li D, Selig ET. Method for railroad track foundation design. I: development. J Geotech Geoenviron Eng ASCE 1998a; 124(4): 316-22. 
Li D, Selig ET. Method for railroad track foundation design. II: appliactions. J Geotech Geoenviron Eng ASCE 1998b; 124(4): 323-29.

Palmeira EM. Soil-geosynthetic interaction: Modelling and analysis. Geotext and Geomembr 2009; 27(5): 368-90.

Qian Y, Mishra D, Tutumluer E, Kazmee HA. Characterization of geogrid reinforced ballast behavior at different levels of degradation through triaxial shear strength test and discrete element modeling. Geotext Geomembr 2015;43(5):393-402.

Raymond GP. Reinforced ballast behaviour subjected to repeated load. Geotext and Geomembr 2002; 20(1): 39-61.

Raymonda G, Ismail I. The effect of geogrid reinforcement on unbound aggregates. Geotext and Geomembr 2003; 21(6): 355-80.

Sayeed MA, Shahin MA. Three dimensional numerical modelling of ballasted railway track foundations for high-speed trains with special reference to critical speed. Transportation Geotechnics 2016; 6: 55-65.

Selig ET, Waters JM. Track geotechnology and substructure management. Thomas Telford, London; 1994.

Shin EC, Kim DH, Das BM. Geogrid-reinforced railroad bed settlement due to cyclic load. Geotech Geol Eng 2002; 20(3): 261-71.

Shukla SK, Yin JH. Fundamentals of geosynthetic engineering, Taylor \& Francis, London; 2006.

Sitharam TG, Hegde A. Design and construction of geocell foundation to support the embankment on settled red mud. Geotext and Geomembr 2013; 41: 55-63.

Sun Q, Indraratna B, Nimbalkar S. Deformation and egradation mechanisms of railway ballast under high frequency cyclic loading. J Geotech Geoenviron Eng ASCE 2016; 142(1): 04015056.

Webster SL, Alford SJ. Investigation of construction concepts for pavements across soft ground. Technical Rep. S-78-6, U.S. Army Engineer Waterways Experiment Station, Vickburg, MS, 1978.

Zhang L, Zhao M, Shi C, Zhao H. Bearing capacity of geocell reinforcement in embankment engineering. Geotext and Geomembr 2010; 28(5): 475-82. 


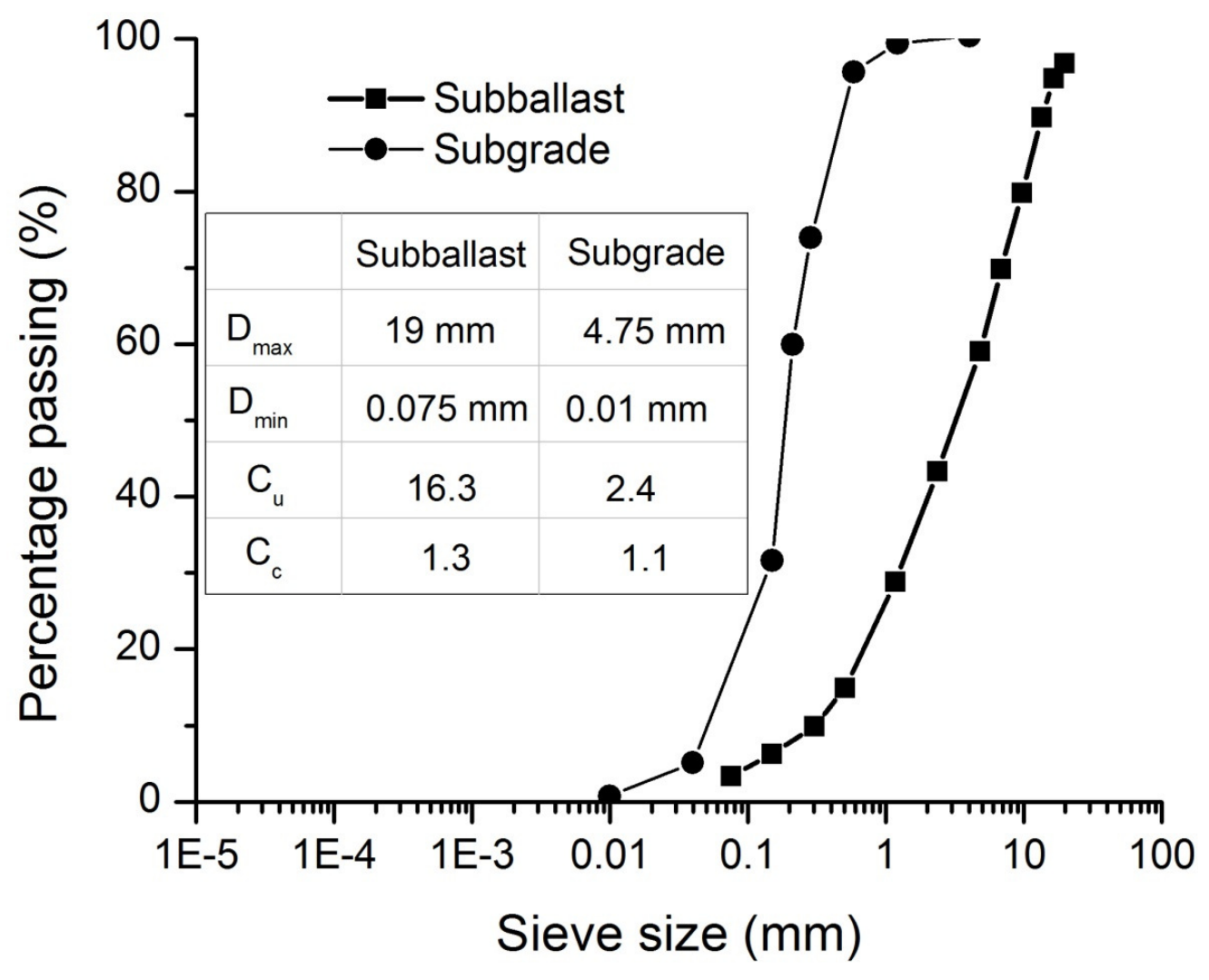

494

Fig. 1. Particle size distribution of subballast and subgrade used in the experiments

495

496 


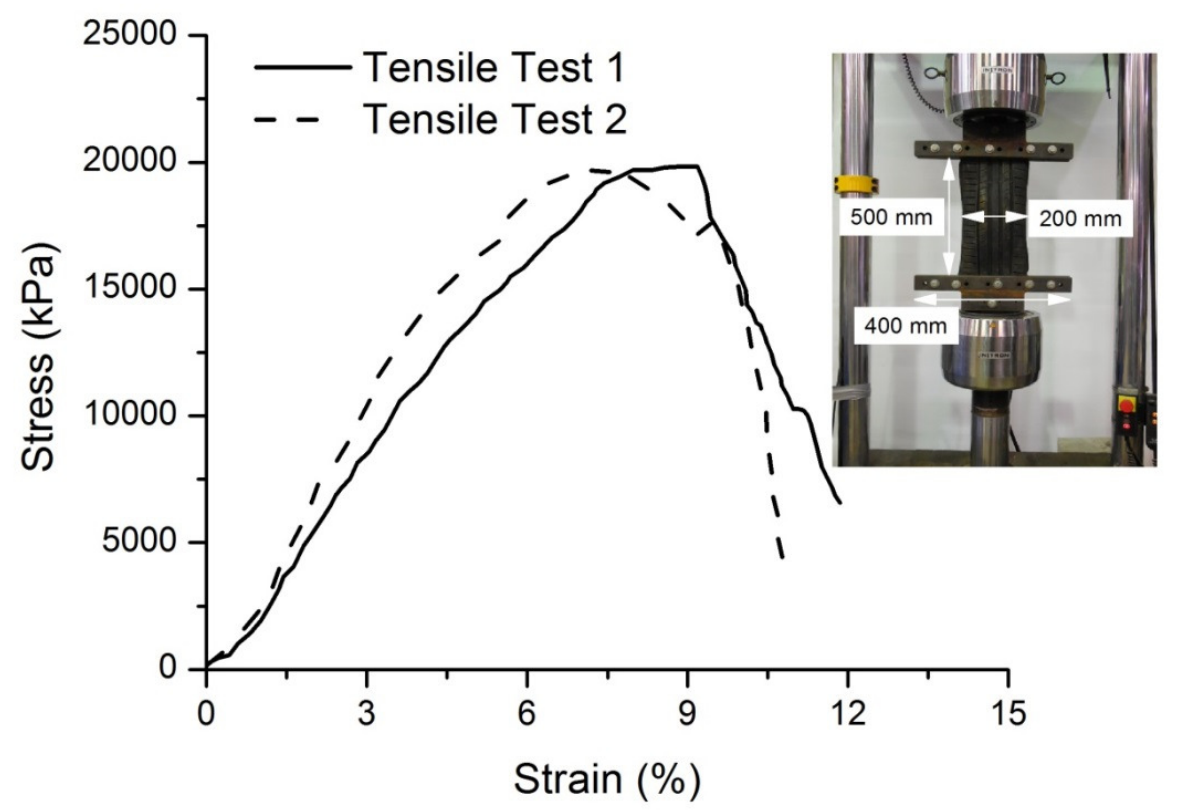

497

Fig. 2. Tensile strength results of the rubber tyre

499

500

501

502

503

504

505

506

507

508

509

510

511

512

513

514

515

516 


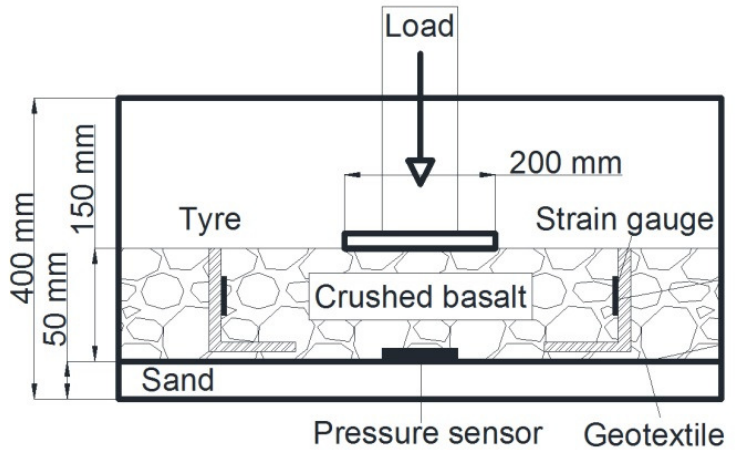

(a)

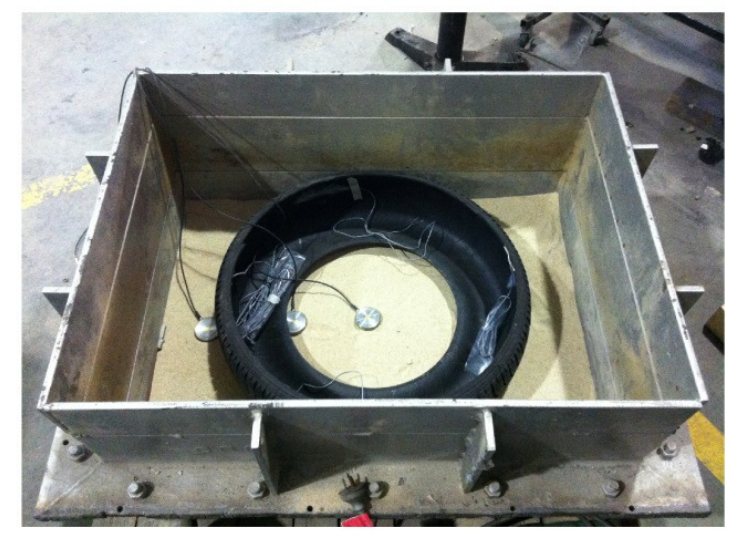

(c)

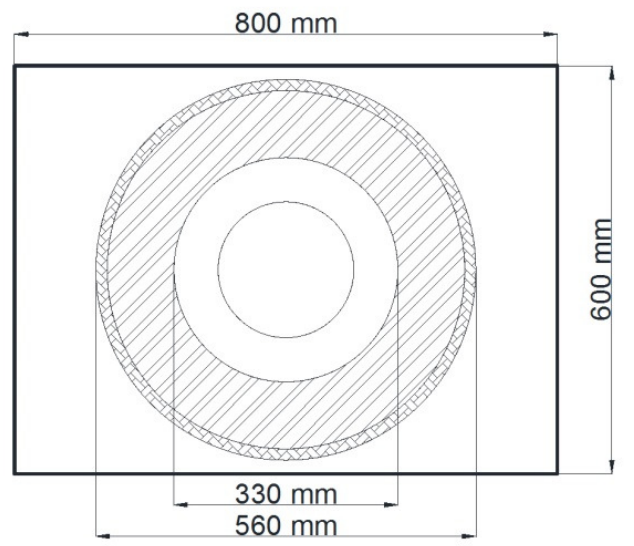

(b)

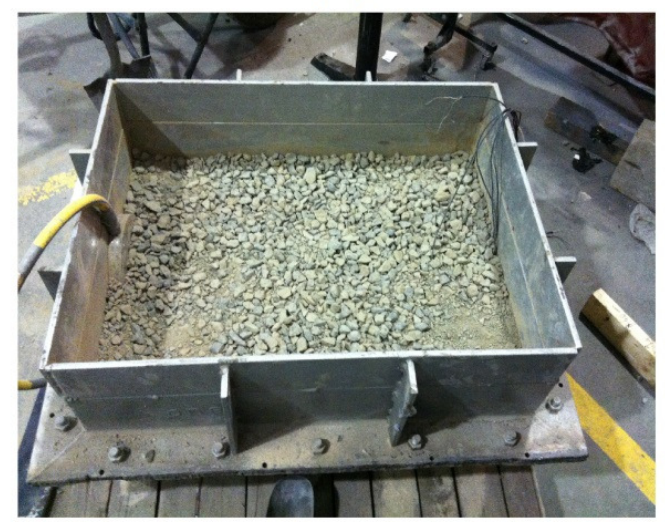

(d)

Fig. 3. Static load test setup: (a\&b) schematic illustration of test box; (c) rubber tyre detail and (d) specimen assembled 

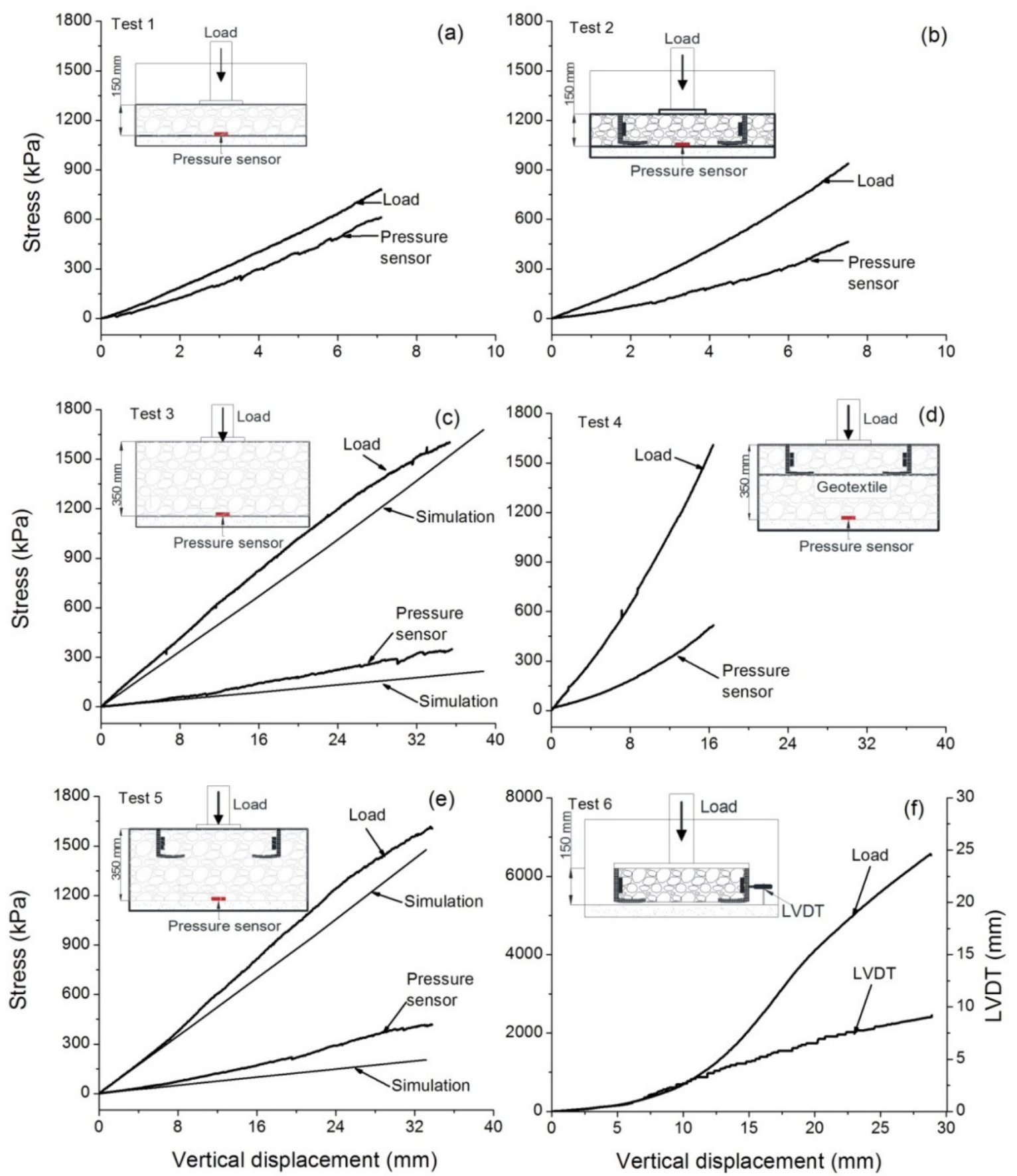

Fig. 4. Results of plate load tests: (a) Test 1: $150 \mathrm{~mm}$ thick of subballast without reinforcement; (b) Test 2: $150 \mathrm{~mm}$ thick of subballast with tyre reinforcement; (c) Test 3:350 mm thick of subballast without reinforcement; (d) Test 4: $350 \mathrm{~mm}$ thick of subballast with tyre and geotextile reinforcement; (e) Test 5: $350 \mathrm{~mm}$ thick of subballast with tyre reinforcement; and (f) Test 6: 
rubber tyre and subballast composite unit cell test
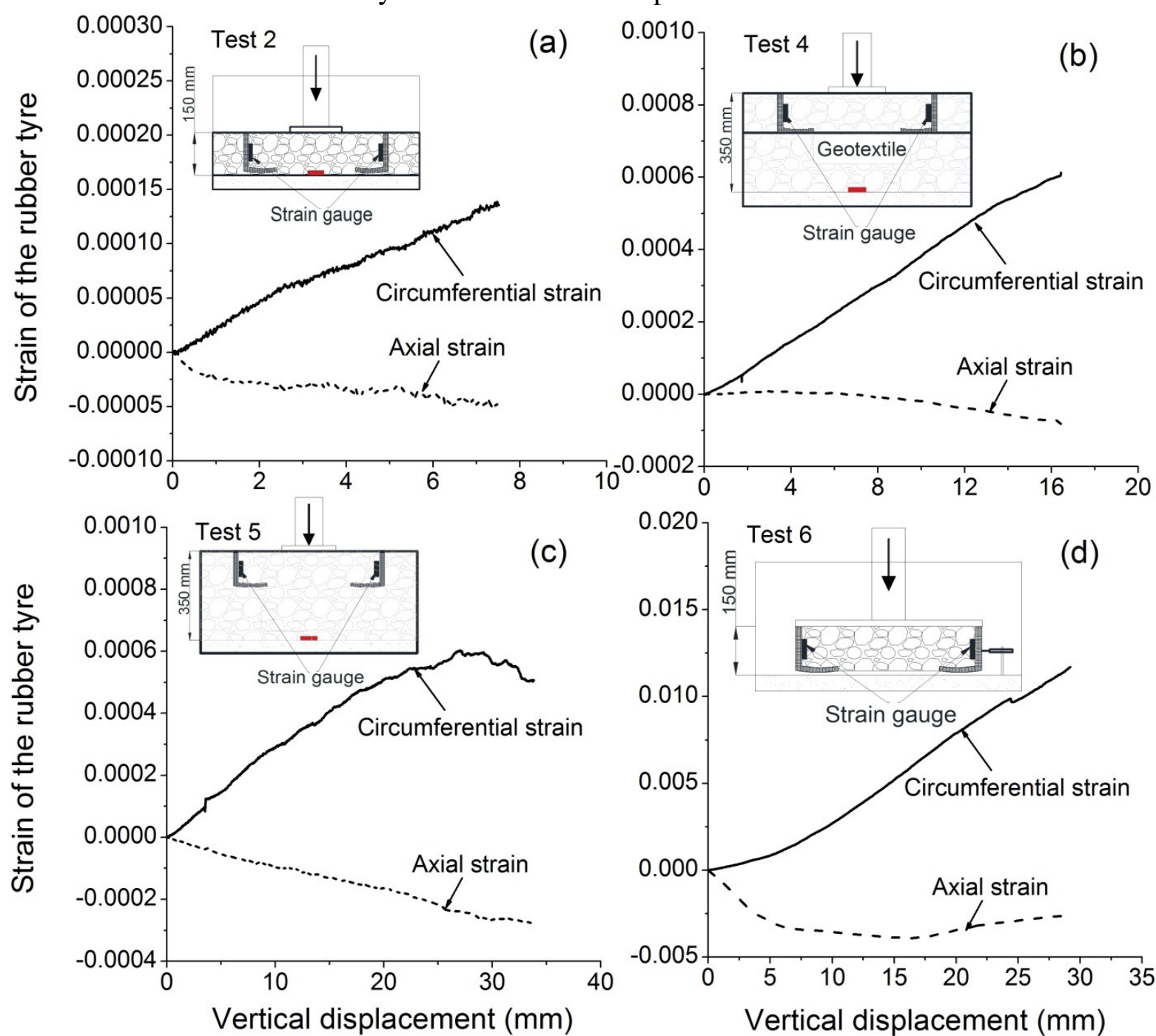

Fig. 5. Circumferential and axial strains of the tyre for the reinforced tests: (a) Test 2: $150 \mathrm{~mm}$ thick of subballast with tyre reinforcement; (b) Test 4: $350 \mathrm{~mm}$ thick of subballast with tyre and geotextile reinforcement; (c) Test 5: $350 \mathrm{~mm}$ thick of subballast with tyre reinforcement; and (d) 


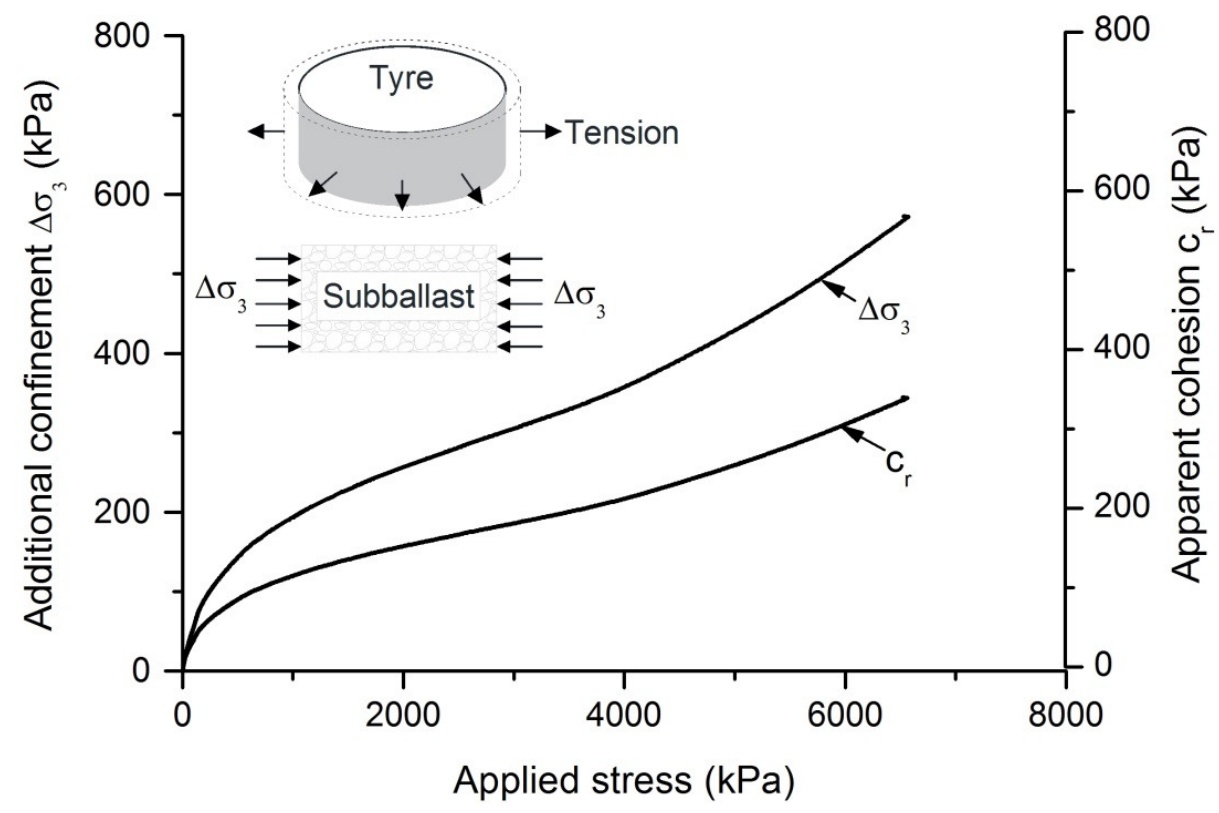

532

Fig. 6. Increment of additional confinement $\Delta \sigma_{3}$ and apparent cohesion $\mathrm{c}_{\mathrm{r}}$ with stress 


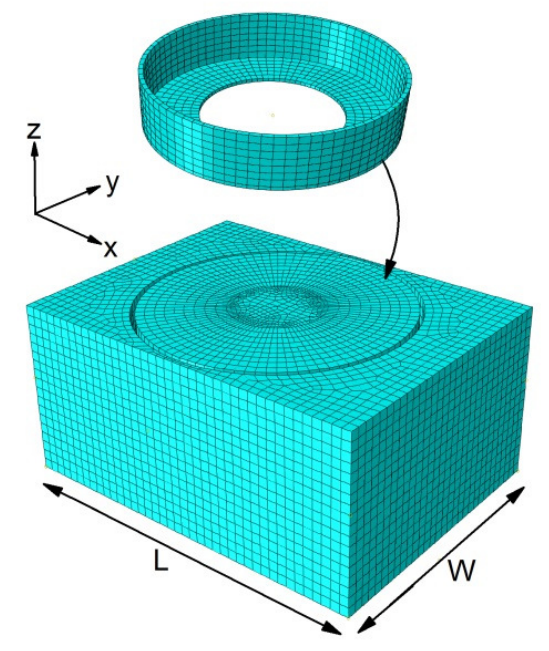

(a)

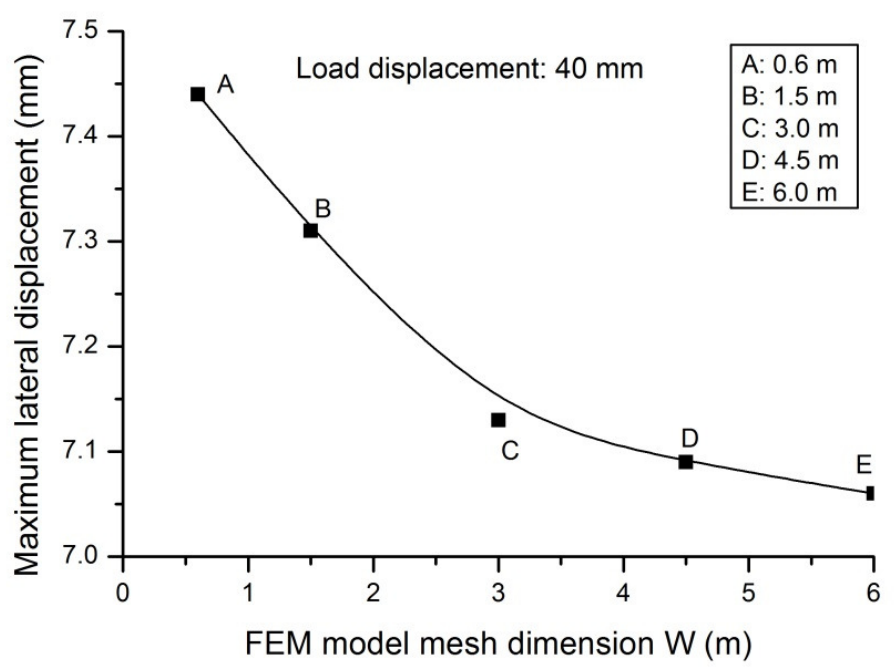

(b)

Fig. 7. (a) 3D ABAQUS mesh for the model with tyre reinforcement and (b) maximum lateral displacement predicted by FE model with different mesh dimension W 

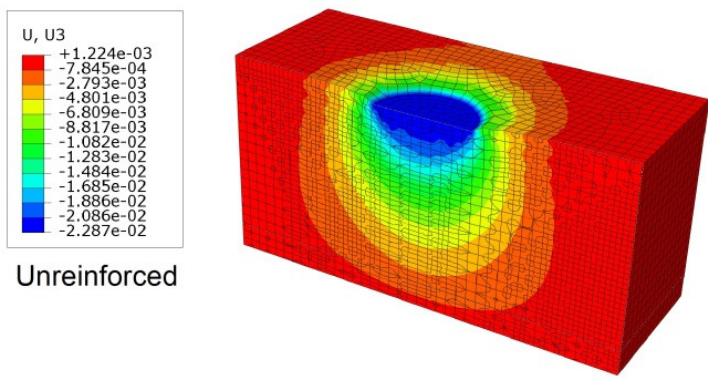

(a)

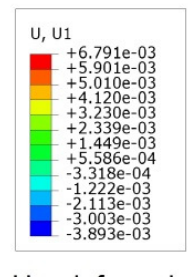

Unreinforced

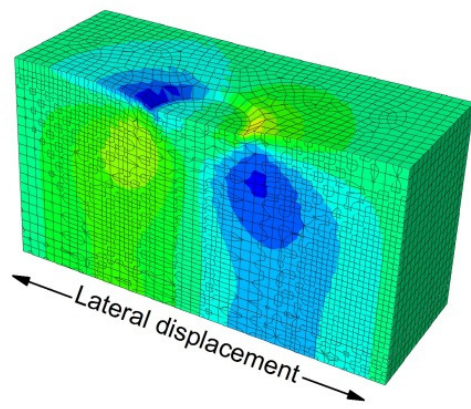

(c)

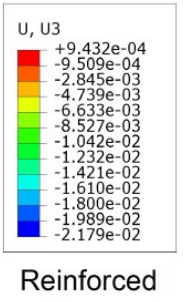

(b)

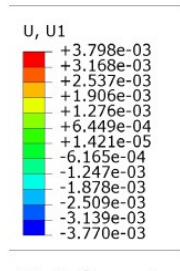

Reinforced

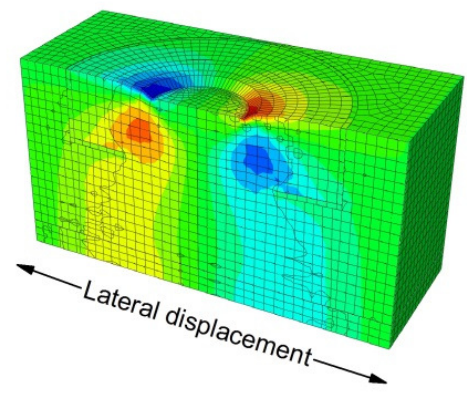

(d)
536

537 Fig. 8. (a) unreinforced vertical displacement at a vertical pressure of $1000 \mathrm{kPa}$; (b) reinforced vertical displacement at a vertical pressure of $1000 \mathrm{kPa}$; (c) unreinforced lateral displacement at a vertical pressure of $1000 \mathrm{kPa}$ and (d) reinforced lateral displacement at a vertical pressure of $1000 \mathrm{kPa}$ 


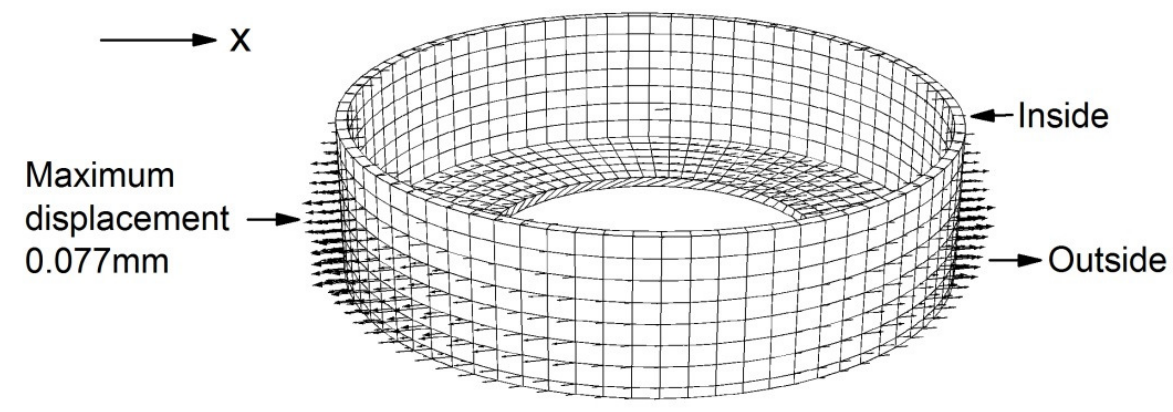

(a)

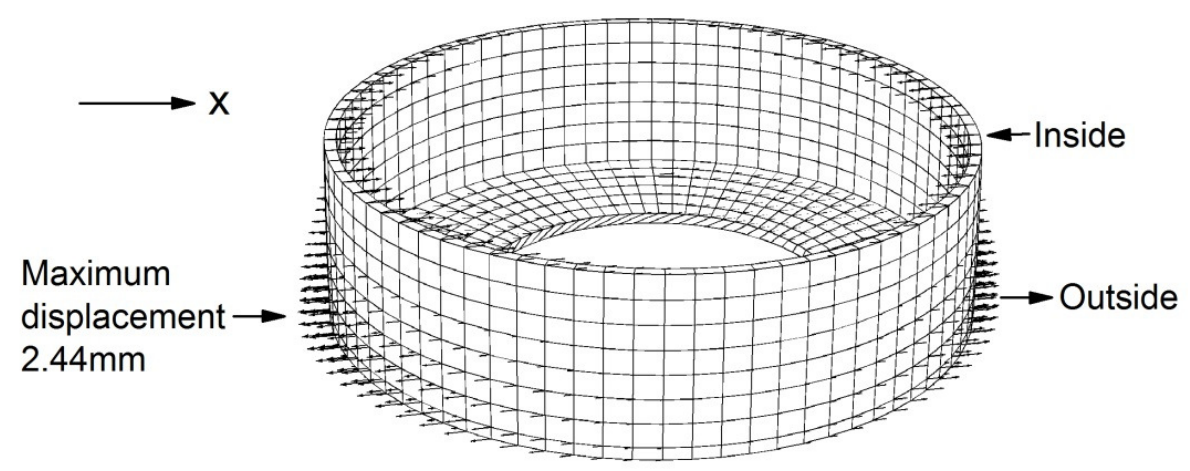

(b)

542

543 Fig. 9. Displacement vectors of rubber tyre along x direction: (a) at a vertical pressure of $50 \mathrm{kPa}$

544

and (b) at a vertical pressure of $1500 \mathrm{kPa}$

545 

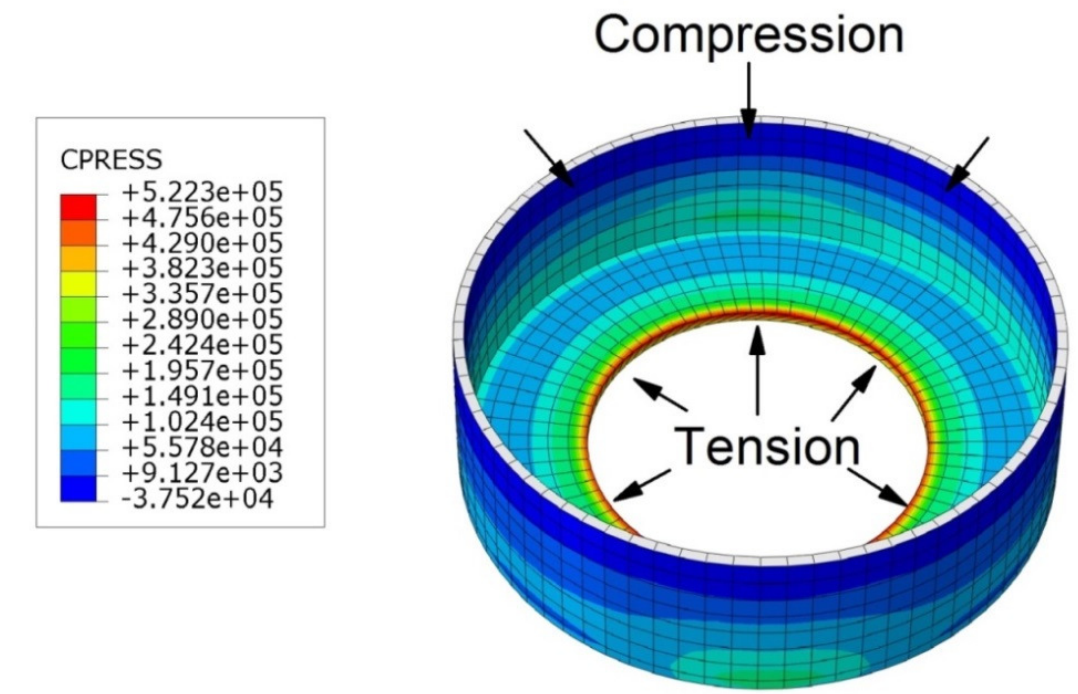

Fig. 10. Force distribution in rubber tyre at a vertical pressure of $1500 \mathrm{kPa}$ 

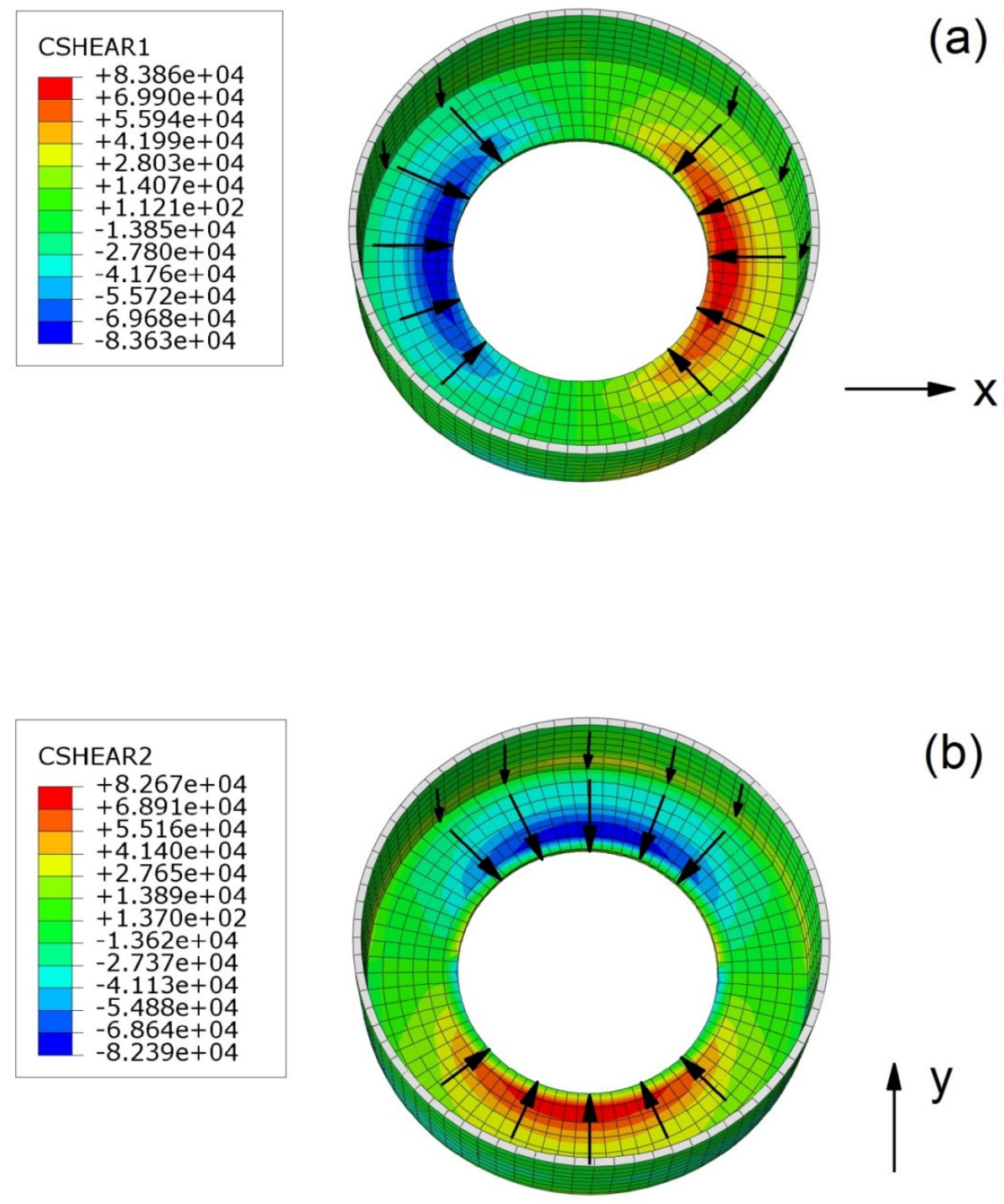

549

550 Fig. 11. Interface shear stress between tyre and subballast at a vertical pressure of $1500 \mathrm{kPa}$ 


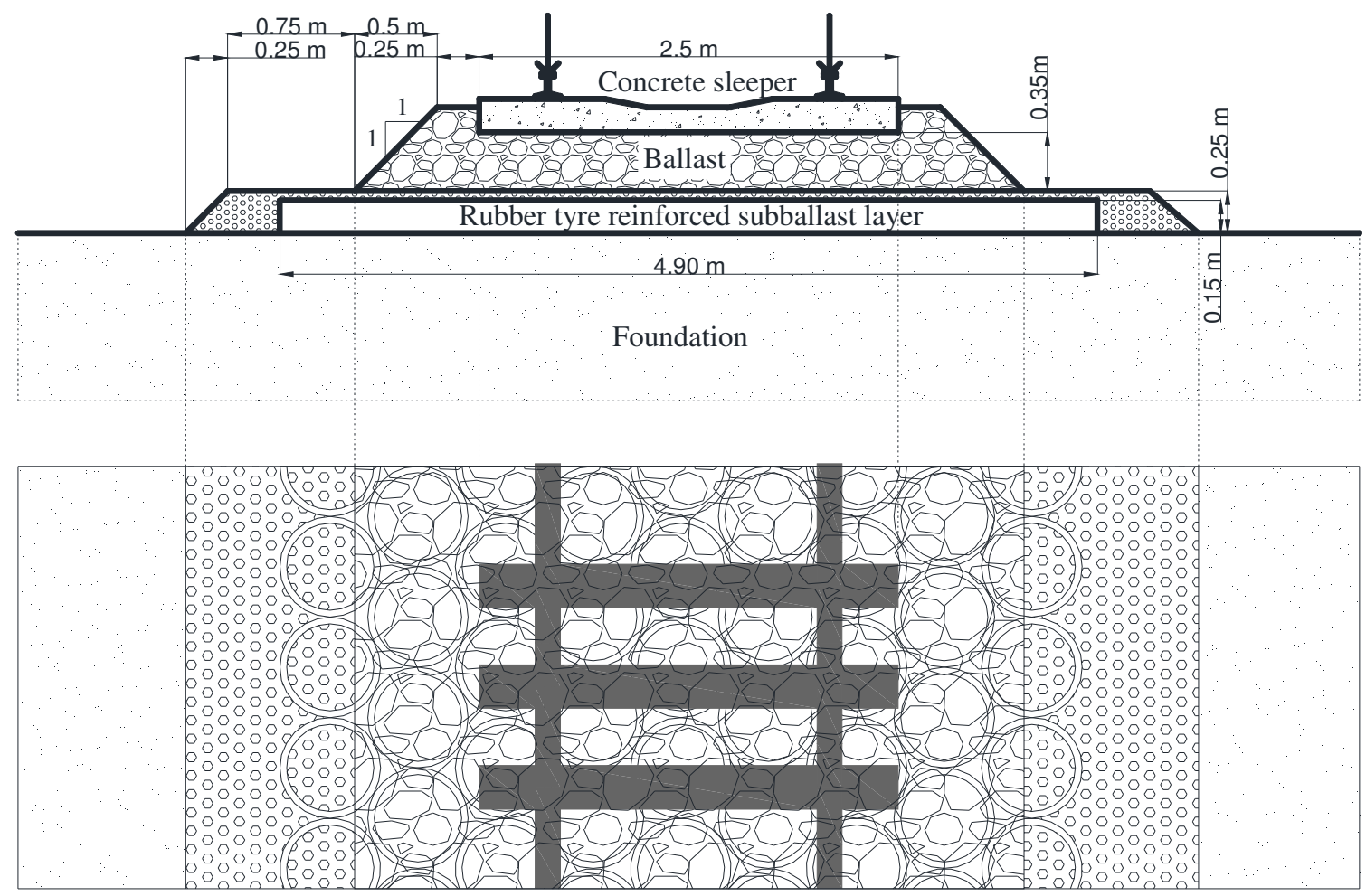




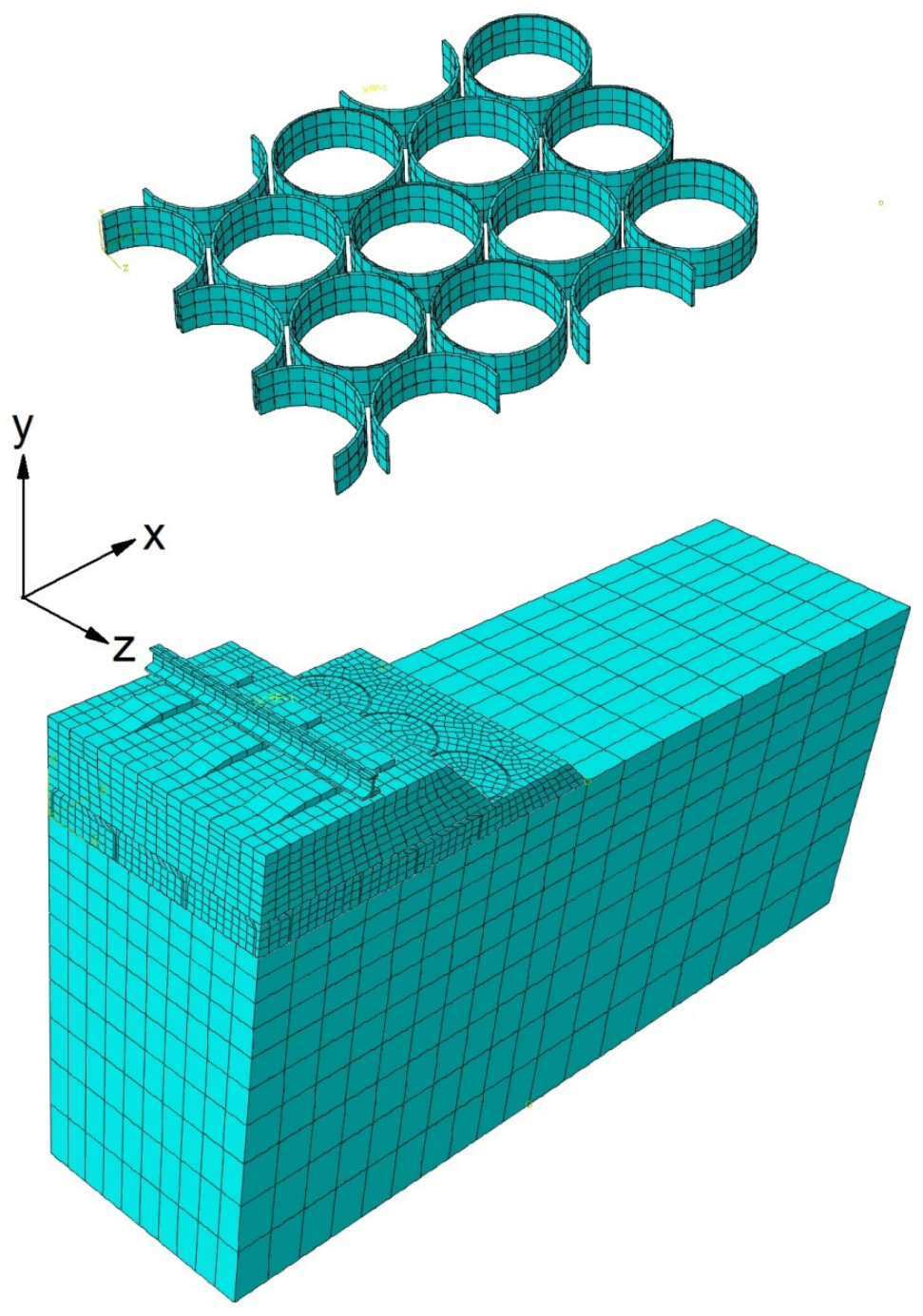




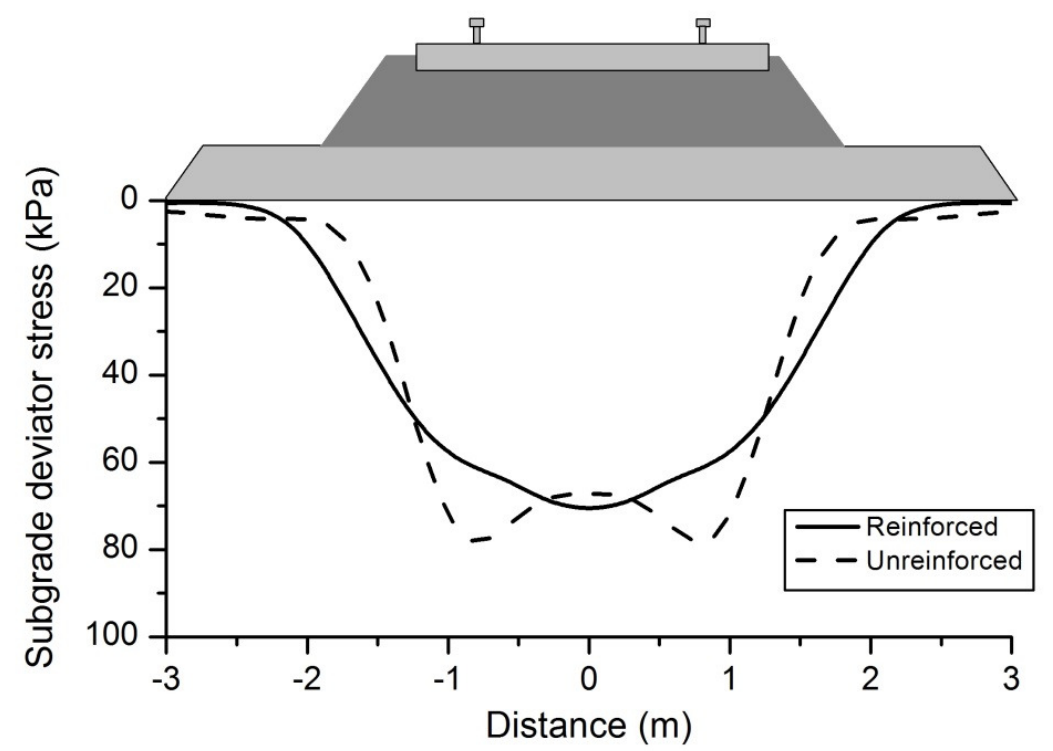

(a)

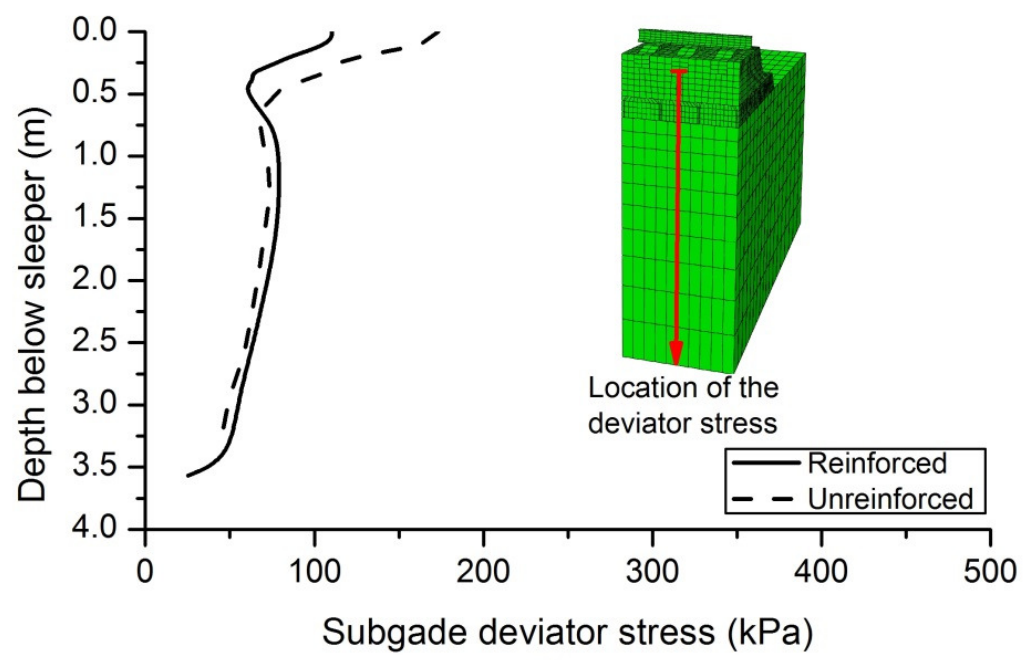

(b)

Fig. 14. (a) Subgrade stress distribution below reinforced and unreinforced track and (b) distribution of subgrade deviator stress with depth for reinforced and unreinforced track 


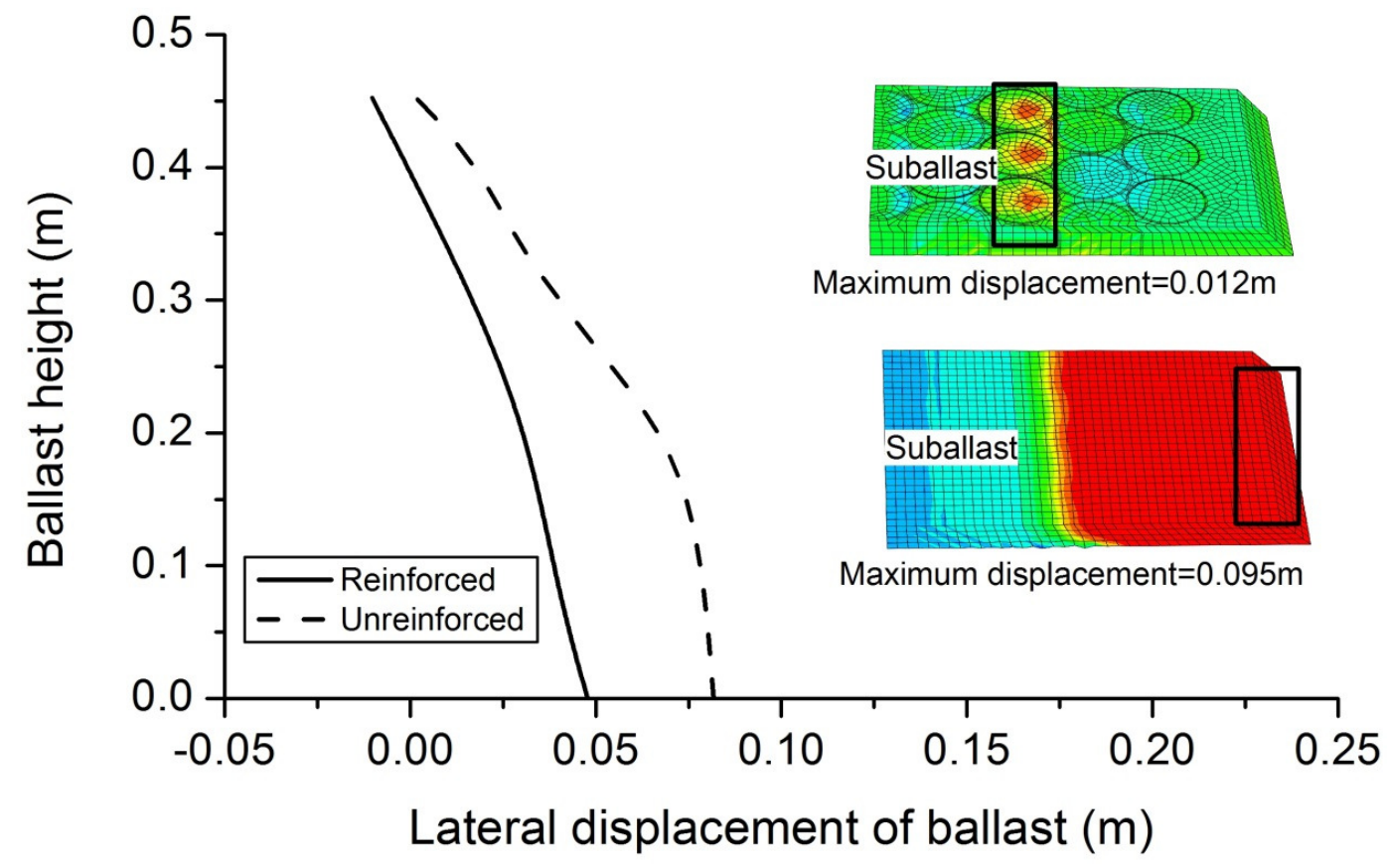

Fig. 15. Lateral displacements for reinforced and unreinforced railway track with various train speed loadings 

for the study

\begin{tabular}{|c|c|c|c|}
\hline \multirow{7}{*}{$\begin{array}{c}\text { Subballast } \\
\text { (crushed basalt) }\end{array}$} & Properties & Values & Satandard \\
\hline & $\mathrm{D}_{\max }(\mathrm{mm})$ & 19 & -- \\
\hline & $\mathrm{D}_{\min }(\mathrm{mm})$ & 0.075 & -- \\
\hline & $\mathrm{C}_{\mathrm{u}}$ & 16.3 & -- \\
\hline & $\mathrm{C}_{\mathrm{c}}$ & 1.3 & -- \\
\hline & $\gamma_{\mathrm{d}}\left(\mathrm{kN} / \mathrm{m}^{3}\right)$ & 21 & -- \\
\hline & $\begin{array}{c}\text { Internal angle of } \\
\text { friction, } \phi \text { (degrees) }\end{array}$ & 39 & $\begin{array}{c}\text { ASTM D4885- } \\
01(2011)\end{array}$ \\
\hline \multirow{5}{*}{$\begin{array}{c}\text { Subgrade } \\
\text { (clayey sand) }\end{array}$} & $\mathrm{D}_{\max }(\mathrm{mm})$ & 4.75 & -- \\
\hline & $\mathrm{D}_{\min }(\mathrm{mm})$ & 0.01 & -- \\
\hline & $\mathrm{C}_{\mathrm{u}}$ & 2.4 & -- \\
\hline & $\mathrm{C}_{\mathrm{c}}$ & 1.1 & -- \\
\hline & $\gamma_{\mathrm{d}}\left(\mathrm{kN} / \mathrm{m}^{3}\right)$ & 17 & -- \\
\hline \multirow{6}{*}{ Tyre } & $\begin{array}{l}\text { Outside diameter } \\
(\mathrm{mm})\end{array}$ & 560 & -- \\
\hline & Rim diameter $(\mathrm{mm})$ & 330 & -- \\
\hline & Width (mm) & 150 & -- \\
\hline & $\begin{array}{c}\text { Tensile stress at } 2 \% \\
\text { strain }(\mathrm{MPa})\end{array}$ & 6.1 & $\begin{array}{c}\text { ASTM D4885- } \\
01(2011)\end{array}$ \\
\hline & $\begin{array}{c}\text { Tensile stress at } 2 \% \\
\text { strain }(\mathrm{MPa})\end{array}$ & 15.2 & $\begin{array}{c}\text { ASTM D4885- } \\
01(2011)\end{array}$ \\
\hline & $\begin{array}{l}\text { Ultimate tensile } \\
\text { strength }(\mathrm{MPa})\end{array}$ & 19.45 & $\begin{array}{l}\text { ASTM D4885- } \\
\text { 01(2011) }\end{array}$ \\
\hline \multirow{7}{*}{ Geotextile } & $\begin{array}{l}\text { Tensile strength } \\
(\mathrm{kN} / \mathrm{m})\end{array}$ & 16.8 & AS3706.2-12 \\
\hline & $\begin{array}{l}\text { Tensile Elongation } \\
(\%)\end{array}$ & $<24$ & AS3706.2-12 \\
\hline & $\begin{array}{l}\text { Tensile Strength at } \\
2 \% \text { Strain }(\mathrm{kN} / \mathrm{m})\end{array}$ & 4 & AS3706.2-12 \\
\hline & $\begin{array}{l}\text { Tensile Strength at } \\
5 \% \text { Strain }(\mathrm{kN} / \mathrm{m})\end{array}$ & 8 & AS3706.2-12 \\
\hline & G Rating & 2800 & Austroads \\
\hline & $\begin{array}{c}\text { Flow rate at } 100 \mathrm{~mm} \\
\text { head }\left(1 / \mathrm{m}^{2} / \mathrm{s}\right)\end{array}$ & 40 & AS3706.9-12 \\
\hline & Permittivity $\left(\mathrm{s}^{-1}\right)$ & 0.4 & AS3706.9-12 \\
\hline
\end{tabular}


Table 2 Track variable values used in the numerical analysis

\begin{tabular}{|c|c|}
\hline Track variable & Value \\
\hline \multicolumn{2}{|c|}{ Rail Properties } \\
\hline Density $\left(\mathrm{kg} / \mathrm{m}^{3}\right)$ & 2000 \\
\hline Young's modulus E (MPa) & 500000 \\
\hline Poisson's ratio, $v$ & 0.3 \\
\hline \multicolumn{2}{|c|}{ Sleeper Properties } \\
\hline Density $\left(\mathrm{kg} / \mathrm{m}^{3}\right)$ & 2000 \\
\hline Young's modulus E (MPa) & 30000 \\
\hline Poisson's ratio, $v$ & 0.25 \\
\hline \multicolumn{2}{|c|}{ Ballast Layer } \\
\hline Density $\left(\mathrm{kg} / \mathrm{m}^{3}\right)$ & 1530 \\
\hline Young's modulus E (MPa) & 2 \\
\hline Poisson's ratio, $v$ & 0.3 \\
\hline Internal angle of friction, $\phi$ (degrees) & 45 \\
\hline Angle of dilation, $\psi$ (degrees) & 15 \\
\hline Cohesion, $\mathrm{c}(\mathrm{kPa})$ & 1 \\
\hline Thickness (m) & 0.35 \\
\hline \multicolumn{2}{|c|}{ Subballast Layer } \\
\hline Density $\left(\mathrm{kg} / \mathrm{m}^{3}\right)$ & 2100 \\
\hline Young's modulus E (MPa) & 2 \\
\hline Poisson's ratio, $v$ & 0.3 \\
\hline Internal angle of friction, $\phi$ (degrees) & 39 \\
\hline Angle of dilation, $\psi$ (degrees) & 15 \\
\hline Cohesion, $\mathrm{c}(\mathrm{kPa})$ & 1 \\
\hline \multicolumn{2}{|c|}{ Subgrade Layer } \\
\hline Density $\left(\mathrm{kg} / \mathrm{m}^{3}\right)$ & 1700 \\
\hline Young's modulus E (MPa) & 2 \\
\hline Poisson's ratio, $v$ & 0.3 \\
\hline Internal angle of friction, $\phi$ (degrees) & 40 \\
\hline Angle of dilation, $\psi$ (degrees) & 15 \\
\hline Cohesion, $\mathrm{c}(\mathrm{kPa})$ & 5 \\
\hline \multicolumn{2}{|c|}{ Tyre Properties } \\
\hline Density $\left(\mathrm{kg} / \mathrm{m}^{3}\right)$ & 1500 \\
\hline Young's modulus E (MPa) & 750 \\
\hline Poisson's ratio, $v$ & 0.35 \\
\hline \multicolumn{2}{|c|}{ Wheel Load } \\
\hline Static wheel load $(\mathrm{kN})$ & 122.5 \\
\hline Train Speed $(\mathrm{km} / \mathrm{h})$ & 100 \\
\hline Dynamic amplification factor (DAF) & 1.54 \\
\hline Dynamic wheel load $(\mathrm{kN})$ & 188.2 \\
\hline \multicolumn{2}{|c|}{ Interface Elements } \\
\hline Normal property & Hard \\
\hline Tangential coefficient & 0.45 \\
\hline
\end{tabular}


Fig. 1. Particle size distribution of subballast and subgrade used in the experiments

Fig. 2. Tensile strength results of the rubber tyre

Fig. 3. Static load test setup: (a\&b) schematic illustration of test box; (c) rubber tyre detail and (d) specimen assembled

Fig. 4. Results of plate load tests: (a) Test 1: $150 \mathrm{~mm}$ thick of subballast without reinforcement; (b) Test 2: $150 \mathrm{~mm}$ thick of subballast with tyre reinforcement; (c) Test 3: $350 \mathrm{~mm}$ thick of subballast without reinforcement; (d) Test 4: $350 \mathrm{~mm}$ thick of subballast with tyre and geotextile reinforcement; (e) Test 5: $350 \mathrm{~mm}$ thick of subballast with tyre reinforcement; and (f) Test 6: rubber tyre and subballast composite unit cell test

Fig. 5. Circumferential and axial strains of the tyre for the reinforced tests: (a) Test 2: $150 \mathrm{~mm}$ thick of subballast with tyre reinforcement; (b) Test 4: $350 \mathrm{~mm}$ thick of subballast with tyre and geotextile reinforcement; (c) Test 5: $350 \mathrm{~mm}$ thick of subballast with tyre reinforcement; and (d) Test 6: rubber tyre and subballast composite unit cell test

Fig. 6. Increment of additional confinement $\Delta \sigma_{3}$ and apparent cohesion $\mathrm{c}_{\mathrm{r}}$ with stress

Fig. 7. (a) 3D ABAQUS mesh for the model with tyre reinforcement and (b) maximum lateral displacement predicted by FE model with different mesh dimension $\mathrm{W}$

Fig. 8. (a) unreinforced vertical displacement at a vertical pressure of $1000 \mathrm{kPa}$; (b) reinforced vertical displacement at a vertical pressure of $1000 \mathrm{kPa}$; (c) unreinforced lateral displacement at a vertical pressure of $1000 \mathrm{kPa}$ and (d) reinforced lateral displacement at a vertical pressure of $1000 \mathrm{kPa}$

Fig. 9. Displacement vectors of rubber tyre along x direction: (a) at a vertical pressure of $50 \mathrm{kPa}$ and (b) at a vertical pressure of $1500 \mathrm{kPa}$

Fig. 10. Force distribution in rubber tyre at a vertical pressure of $1500 \mathrm{kPa}$

Fig. 11. Interface shear stress between tyre and subballast at a vertical pressure of $1500 \mathrm{kPa}$

Fig. 12. Track geometry with rubber tyres reinforced capping (subballast) layer

Fig. 13. FEM mesh of ballasted railway track and foundation reinforced with rubber tyres in the subballast layer

Fig. 14. (a) Subgrade stress distribution below reinforced and unreinforced track and (b) distribution of subgrade deviator stress with depth for reinforced and unreinforced track

Fig. 15. Lateral displacements for reinforced and unreinforced railway track with various train speed loadings 